\title{
International harmony on plans for the US space station
}

\section{Washington}

THE prospects for international collaboration in the US space station brightened last week after two days of discussion in Washington between representatives of the European Space Agency (ESA) and the National Aeronautics and Space Administration (NASA).

Andrew Stofan, associate administrator of the NASA Office of Space Station. said that after "eleven months of struggling. everything seems to have broken free at one time". both because of progress in international negotiations and because of support given to space station funding in Congress.

International collaboration had seemed on the verge of collapse after US Defense Secretary. Caspar Weinberger, had insisted that the Department of Defense be allowed to use the station for military research (see Nature 326, 727; 1987), in defiance of earlier promises that the station would be used for peaceful purposes only. Now there has been progress towards a form of words for an agreement that satisfies European desires that the station be used for peaceful purposes consistent with international law, while leaving certain military options open.

Negotiations in Washington were not disturbed by a row between Weinberger and Representative Norman Mineta (Democrat, California) who had proposed a bill to prohibit use of the space station for weapons research. Assurances were given that Weinberger's angry protest comparing Mineta's ideas to "Soviet propaganda" was not aimed at an international audience.

ESA representatives are also very pleased, according to Stofan, that NASA has accepted the man-tended free-flying laboratory (MTFL) as part of the project. MTFL will be launched by an Ariane 5 rocket and rendezvous with the space station twice a year for refurbishment. The rest of the time it will fly free, providing a low-gravity environment for experiments, undisturbed by dockings of the space shuttle and movements of space station personnel.

\section{Government money on the table for bankrupt college}

London

THE British government has handed a $£ 10$ million lifeline to University College, Cardiff, to rescue it from possible bankruptcy, after charges of serious financia mismanagement. The interest-free loan and grants will be made only on the condition that the college dismisses or obtains the resignation of its principal, Dr C.W.L. Bevan, and "takes all reasonable steps" to sue or surcharge any staff responsible for financial losses to the university.

The rescue package is spelled out in a letter from the University Grants Committee (UGC), after months of investigation into the college's financial crisis. The government had earlier warned that the institution's grant would be withdrawn unless there were changes in the top management. Last week saw the resignation of four senior staff, and the bursar resigned earlier this term.

The college was facing debts of up to $£ 7$ million, brought about by what an inquiry set up by the acting principal Professor Lee Sheridan called a "tangle of uncosted schemes, arbitrary authorizations and irregular salary payments". The $£ 10$ million will be made available only if University College, Cardiff, amalgamates with the University of Wales Institute of Science and Technology, and overhauls its financial management.
Academic and financial plans for the new amalgamated institution must be approved by the UGC. A meeting is expected soon between the college and the UGC to discuss details, including proposals made by a college committee which would mean nearly 140 redundancies and the amalgamation of some departments. "The money will give us breathing space, but it doesn't solve the problems", a college spokesman said. The rescue package includes a $£ 5$ million loan from the government, which will have to be paid back by the sale of buildings and land when the new institution is set up; other funds in the package will cover staff redundancies.

The college's principal, Dr Bevan, has been on sabbatical since March, and he has not yet said if he will resign. He has been principal of the 6,000 -student college for 21 years, and has survived a number of no-confidence motions by the college senate and its staff. Last month the college council refused to dismiss Bevan despite a recommendation from an inquiry into the financial crisis.

The Department of Education and Science has been scrutinizing the finances since early last year, when it commissioned an independent report which criticized the management. Bevan was quoted as calling the report "a bag of wind".

Kathy Johnston
Despite NASA's official optimism, there are still risks that funding will not be found, and that the project will not survive changes in the administration that will follow next year's presidential election. Stofan hoped that an independent review of the station's costs and technical plans now being carried out by the National Research Council would help provide a "bridge from one administration to another"

Negotiations with Japanese representatives, who have consistently opposed military use of the space station, will take place next week. Satisfactory talks have already been held with the Canadians, the fourth partner in the station.

Alun Anderson

\section{Medical professors' public complaint}

\section{London}

IN an unprecedented public statement, the Association of Clinical Professors of Medicine has highlighted the demise of nondrug-related medical research and the "rock-bottom morale" of research staff in Britain.

The criticisms, which are levelled at the government's attitude to the support of research, are contained in the association's submission to the subcommittee on priorities in medical research of the House of Lords Select Committee on Science and Technology. The association, whose membership is composed of 150 universitybased professors of medicine and related clinical subjects, for the first time has "now expressed publicly deep anxieties about the future of medical research in the UK". While the association admits it is experiencing what scientists in other areas have already identified, it claims that there are problems resulting from the present government's policies "which affect clinical research in particular".

The statement to the House of Lords claims that the loss of certain university funds is having a dramatic impact on the direction of research effort. Greater reliance is now being placed on the pharmaceutical industry, which provides money for clinical trials of drugs. As a consequence, substantial areas of medical research are being neglected as "industry is not in general prepared to invest in nondrug-related research, such as preventive medicine, epidemiology, mental illness or the problems of ageing". The association, whose members hold chairs in departments of medicine or allied specialities, blames government cutbacks. Good medical research depends on first-class scientists and good projects. "These we have, until now, had in abundance, though we are now losing more and more good people abroad."

Bill Johnstone 